\title{
BODY FLUID AND ELECTROLYTE COMPOSITION IN ARTERIAL HYPERTENSION. II. STUDIES IN MINERALOCORTICOID HYPERTENSION *
}

\author{
By A. V. CHOBANIAN, B. A. BURROWS AND W. HOLLANDER $\dagger$ with the teChNICAL \\ ASSISTANCE OF VALENTINE BIKERMAN \\ (From the Robert Dawson Evans Memorial, Massachusetts Memorial Hospitals, the Radio- \\ isotope and Medical Services, Boston Veterans Administration Hospital, and the \\ Department of Medicine, Boston University School of Medicine, \\ Boston, Mass.)
}

(Submitted for publication August 29, 1960; accepted October 20, 1960)

In a previous report, measurements of body fluid and electrolyte composition have been compared in normal subjects and patients with arterial hypertension (1). In this paper, similar studies are presented in a group of patients with primary hyperaldosteronism studied before and after surgical therapy and in a group of normal subjects given mineralocorticoid drugs. The results indicate that the findings in the patients with established primary hyperaldosteronism differ

* Supported by Contract AT(30-1)919 between the Atomic Energy Commission and the Massachusetts Memorial Hospitals.

† Special Research Fellow, National Institutes of Health. from those in patients with uncomplicated essential, renal and malignant hypertension.

\section{CLINICAL MATERIAL AND METHODS}

Eleven patients with primary hyperaldosteronism and 11 normal control subjects who were matched according to age, sex, weight and surface area were included in the study. All patients had typical findings of primary hyperaldosteronism (2), which in 7 cases was associated with an adrenal adenoma and in 4 cases with adrenal hyperplasia. Every patient had sustained arterial hypertension with diastolic blood pressures in the group ranging from 110 to $140 \mathrm{~mm} \mathrm{Hg}$. Examination of the fundi revealed Grade IV hypertensive retinopathy in 1 patient, Grade III retinopathy in 2 patients and Grade II retinopathy in the remaining 8 patients. None of the patients had evidence of peripheral edema, clinical signs of con-

TABLE I

Primary hyperaldosteronism *

\begin{tabular}{|c|c|c|c|c|c|c|c|c|c|c|c|c|c|}
\hline Subject & Sex & Age & Diagnosis & $\begin{array}{c}\text { Body } \\
\text { wt }\end{array}$ & BSA & $\mathrm{BP}$ & Fundi & $\begin{array}{l}\text { Serum } \\
\text { osm. }\end{array}$ & $\begin{array}{c}\mathrm{ECF} \\
\left(\mathrm{S}^{35} \mathrm{O}_{4}\right. \\
\text { space })\end{array}$ & $\mathrm{Nas}$ & $\mathrm{K}_{\mathbf{s}}$ & $\underset{\text { body wt }}{\mathrm{Nae}^{\prime} /}$ & $\begin{array}{c}\mathrm{K}_{\mathrm{e}} / \\
\text { body wt }\end{array}$ \\
\hline & & $y r s$ & & $k g$ & $m^{2}$ & $m m \mathrm{Hg}$ & grade & $m O s m / L$ & $\begin{array}{c}\% \\
b o d y w t\end{array}$ & $m E q / I$ & $m E q / L$ & $m E q / k g$ & $m E q / k g$ \\
\hline $\begin{array}{l}\text { S.W. } \\
\text { M.C. } \\
\text { J.B. } \\
\text { L.B. } \\
\text { M.A. } \\
\text { D.G. } \\
\text { J.M. } \\
\text { A.H. } \\
\text { C.B. } \\
\text { J.S. } \\
\text { B.G. }\end{array}$ & $\begin{array}{l}\text { M } \\
F \\
F \\
F \\
M \\
F \\
M \\
F \\
M \\
M \\
F\end{array}$ & $\begin{array}{l}47 \\
37 \dagger \\
48 \dagger \\
31 \\
51 \\
35 \\
56 \dagger \\
46 \\
47 \dagger \\
65 \\
33\end{array}$ & $\begin{array}{l}\text { Rt. ad. adenoma } \\
\text { Rt. ad. adenoma } \\
\text { Bilat. ad. hyperplasia } \\
\text { Lt. ad. adenoma } \\
\text { Lt. ad. hyperplasia } \\
\text { Lt. ad. adenoma } \\
\text { Bilat. ad. hyperplasia } \\
\text { Lt. ad. adenoma } \\
\text { Rt. ad. adenoma } \\
\text { Bilat. ad. hyperplasia } \\
\text { Lt. ad. adenoma }\end{array}$ & $\begin{array}{l}64.5 \\
60.0 \\
57.8 \\
56.8 \\
82.1 \\
53.4 \\
83.6 \\
51.8 \\
68.2 \\
69.1 \\
61.8\end{array}$ & $\begin{array}{l}1.76 \\
1.68 \\
1.57 \\
1.56 \\
1.92 \\
1.58 \\
2.07 \\
1.48 \\
1.84 \\
1.72 \\
1.68\end{array}$ & $\begin{array}{l}235 / 140 \\
180 / 110 \\
210 / 125 \\
200 / 130 \\
165 / 110 \\
190 / 120 \\
215 / 130 \\
210 / 125 \\
220 / 135 \\
205 / 120 \\
210 / 120\end{array}$ & $\begin{array}{l}\text { III } \\
\text { II } \\
\text { IV } \\
\text { II } \\
\text { II } \\
\text { II } \\
\text { III } \\
\text { II } \\
\text { II } \\
\text { II } \\
\text { II }\end{array}$ & $\begin{array}{l}293 \\
291 \\
277 \\
296 \\
287 \\
295 \\
289 \\
294 \\
290 \\
291 \\
292\end{array}$ & $\begin{array}{l}16.2 \\
15.8 \\
15.9 \\
16.5 \\
12.9 \\
17.0 \\
20.2\end{array}$ & $\begin{array}{l}149 \\
141 \\
137 \\
145 \\
138 \\
140 \\
139 \\
148 \\
142 \\
144 \\
145\end{array}$ & $\begin{array}{l}2.7 \\
2.5 \\
2.5 \\
2.9 \\
3.5 \\
2.6 \\
3.3 \\
2.8 \\
3.5 \\
3.0 \\
2.6\end{array}$ & $\begin{array}{l}48.8 \\
48.5 \\
38.7 \\
40.2 \\
44.5 \\
44.1 \\
33.8 \\
42.7 \\
38.5 \\
46.9 \\
42.4\end{array}$ & $\begin{array}{l}30.5 \\
19.6 \\
24.2 \\
23.4 \\
31.6 \\
28.5 \\
27.5 \\
27.3 \\
29.3 \\
22.5\end{array}$ \\
\hline \multicolumn{14}{|c|}{ Control } \\
\hline $\begin{array}{l}\text { E.H. } \\
\text { S.R. } \\
\text { A.J. } \\
\text { M.D. } \\
\text { A.F. } \\
\text { M.M. } \\
\text { H.D. } \\
\text { S.M. } \\
\text { J.W. } \\
\text { S.W. } \\
\text { E.K. }\end{array}$ & $\begin{array}{l}M \\
F \\
F \\
F \\
M \\
F \\
M \\
F \\
M \\
M \\
F\end{array}$ & $\begin{array}{l}48 \\
45 \\
43 \\
33 \\
49 \\
41 \\
52 \\
37 \\
49 \\
63 \\
49\end{array}$ & $\begin{array}{l}\text { Normal } \\
\text { Normal } \\
\text { Normal } \\
\text { Normal } \\
\text { Normal } \\
\text { Normal } \\
\text { Normal } \\
\text { Normal } \\
\text { Normal } \\
\text { Normal } \\
\text { Normal }\end{array}$ & $\begin{array}{l}66.6 \\
49.5 \\
66.3 \\
66.4 \\
81.8 \\
52.0 \\
80.3 \\
50.9 \\
66.4 \\
68.2 \\
66.8\end{array}$ & $\begin{array}{l}1.75 \\
1.50 \\
1.65 \\
1.76 \\
1.91 \\
1.51 \\
1.95 \\
1.55 \\
1.81 \\
1.71 \\
1.61\end{array}$ & $\begin{array}{l}125 / 80 \\
125 / 75 \\
100 / 65 \\
105 / 65 \\
125 / 75 \\
115 / 75 \\
115 / 80 \\
120 / 75 \\
110 / 65 \\
130 / 80 \\
100 / 60\end{array}$ & $\begin{array}{l}0 \\
0 \\
0 \\
0 \\
0 \\
0 \\
0 \\
0 \\
0 \\
0 \\
0\end{array}$ & $\begin{array}{l}289 \\
289 \\
288 \\
279 \\
297 \\
277 \\
287 \\
290 \\
293 \\
288 \\
287\end{array}$ & $\begin{array}{l}14.0 \\
16.1 \\
15.9 \\
16.5 \\
14.3 \\
15.0 \\
11.2 \\
13.8\end{array}$ & $\begin{array}{l}140 \\
140 \\
143 \\
138 \\
146 \\
137 \\
141 \\
141 \\
140 \\
139 \\
140\end{array}$ & $\begin{array}{l}4.3 \\
4.2 \\
3.8 \\
4.3 \\
4.8 \\
3.6 \\
4.4 \\
4.0 \\
3.7 \\
3.9 \\
4.5\end{array}$ & $\begin{array}{l}42.0 \\
36.7 \\
37.8 \\
38.0 \\
37.7 \\
34.8 \\
39.8 \\
32.5 \\
40.5 \\
33.4 \\
33.9\end{array}$ & $\begin{array}{l}40.5 \\
43.2 \\
34.7 \\
35.0 \\
38.3 \\
33.4 \\
39.1 \\
32.2 \\
54.5\end{array}$ \\
\hline
\end{tabular}

$* \mathrm{BSA}=$ body surface area. $\mathrm{BP}=$ blood pressure. $\mathrm{ECF}=$ extracellular fiuid volume. $\mathrm{Na}_{\mathrm{s}}=$ serum sodium. $\mathrm{K}_{\mathrm{s}}=$ serum potassium. $\mathrm{Na}$

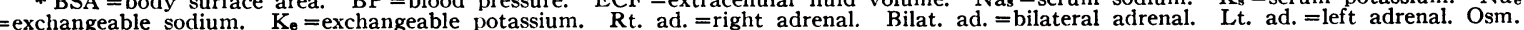
=osmolarity.

t Values are means of 2 or more determinations. 
gestive heart failure or nitrogen retention. Serum osmolality, radiosulfate space $\left(\mathrm{S}^{35} \mathrm{O}_{4}\right)$, serum sodium $\left(\mathrm{Na}_{\mathbf{s}}\right)$, serum potassium $\left(\mathrm{K}_{\mathrm{s}}\right)$, total exchangeable sodium $\left(\mathrm{Na}_{\mathrm{e}}\right)$ and total exchangeable potassium $\left(\mathrm{K}_{\mathbf{e}}\right)$ were measured according to previously described methods (1). In 9 of the patients with aldosteronism, these studies were repeated within 6 weeks to 16 months following adrenal surgery for treatment of the aldosteronism and in 2 patients following preoperative supplementary potassium administration.

In addition, 8 normal subjects were treated with either $9-\alpha$-fluorohydrocortisone in daily oral doses of $1.0 \mathrm{mg}$ or desoxycorticosterone acetate (DCA) in daily intramuscular doses of $20 \mathrm{mg}$. The dietary intake of sodium was controlled at $180 \mathrm{mEq}$ of sodium daily, and potassium intake was unrestricted. Following a 1 week control period, treatment with either fluorohydrocortisone or DCA was instituted and continued for 15 to 21 days. Body weight was recorded daily and blood pressure 4 times daily. Serum Na, serum K, serum osmolality, radiosulfate space, exchangeable sodium and exchangeable potassium were measured during the control period and again at the end of the period of treatment. In Subjects J.W., T.M. and A.C., metabolic balance measurements were made in addition during a 21 day period of fluorohydrocortisone administration when dietary sodium was restricted to less than $9 \mathrm{mEq}$ daily.

In 2 subjects with hyperaldosteronism and in 3 normal subjects simultaneous exchangeable sodium and potassium measurements and metabolic balance studies were carried out.

\section{RESULTS}

\section{Hyperaldosteronism}

The complete results are tabulated in Tables I, II, III and IV.

A. Serum sodium. Serum sodium was increased slightly, but not with statistical significance, in the patients with aldosteronism as compared with the control group, which was matched according to age, sex, weight and surface area. In the aldosterone group following operation, there was a slight reduction in serum sodium, averaging $4.1 \mathrm{mEq}$ per L.

B. Serum potassium. Serum potassium was significantly reduced in the patients with aldosteronism, with a mean value of $2.9 \mathrm{mEq}$ per $\mathrm{L}$ and a range of 2.5 to $3.5 \mathrm{mEq} / \mathrm{L}$ as compared with the control mean of 4.1 and range of 3.6 to $4.8 \mathrm{mEq} / \mathrm{L}$. All patients with aldosteronism showed increases in serum potassium to the normal range following adrenal surgery.

C. Serum osmolality. Serum osmolality was slightly. but not significantly increased in patients with aldosteronism, with a mean value of 290

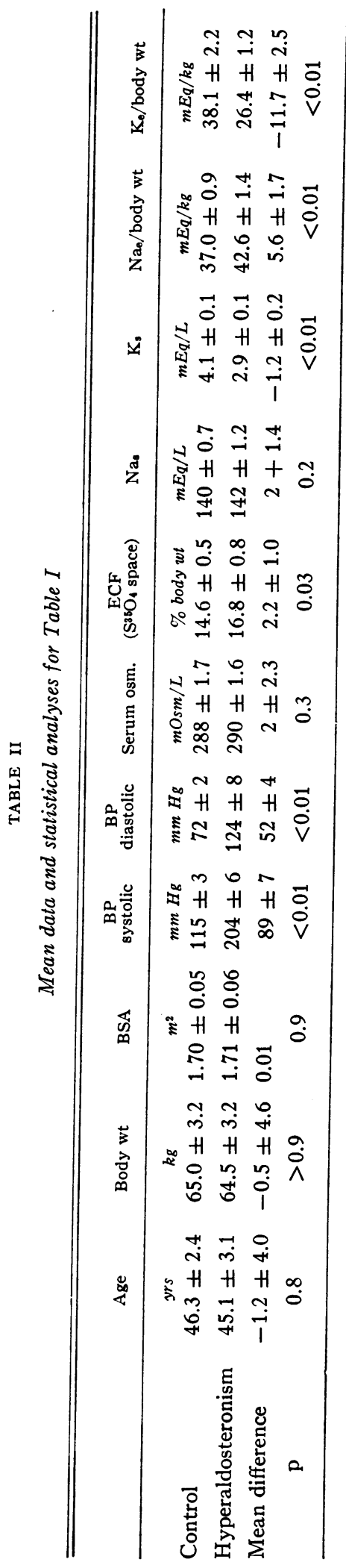


mOsm per $\mathrm{L}$ versus a mean of 288 mOsm per $\mathrm{L}$ in the control group. There was no appreciable change in serum osmolality following adrenal surgery.

D. Radiosulfate space. The radiosulfate space in the aldosterone group was significantly increased, with a mean value of $10.8 \mathrm{~L}$ or 16.8 per cent body weight as against a mean of $9.7 \mathrm{~L}$ or 14.6 per cent body weight in the control group. Postoperatively, there was a mean reduction of $1.3 \mathrm{~L}$ in the eight patients who had these measurements carried out.

E. Exchangeable sodium. Exchangeable sodium in the aldosterone group ranged between 33.8 and $48.8 \mathrm{mEq}$ per $\mathrm{kg}$ body weight as compared with 32.5 to $42.8 \mathrm{mEq}$ per $\mathrm{kg}$ body weight in the control group. There was a mean increase in $\mathrm{Na}_{\mathrm{e}}$ of $342 \mathrm{mEq}$ in the aldosterone group, which was statistically significant. In the group of nine patients studied postoperatively, there was a mean reduction in exchangeable sodium of $201 \mathrm{mEq}$ as compared with their preoperative values. Reductions were not confined to the early postoperative period but continued to occur in comparable amounts in the late postoperative period as well.

F. Exchangeable potassium. Exchangeable potassium was markedly reduced in all patients with aldosteronism, with values ranging from 19.6 to $31.6 \mathrm{mEq}$ per $\mathrm{kg}$ body weight in contrast to the control range of 30.4 to 54.5 . The mean reduction of exchangeable potassium for the group was $774 \mathrm{mEq}$. The two patients studied following potassium loading had increases in exchangeable potassium of 432 and $430 \mathrm{mEq}$. Postoperatively, there was a mean increase in exchangeable potassium of $663 \mathrm{mEq}$ in the nine patients who were studied after adrenal surgery.

G. Blood pressure. All patients have now been followed for more than six months postoperatively. Four patients have had reduction in blood pressure to normal levels, six have had reductions of greater than $20 / 10 \mathrm{~mm} \mathrm{Hg}$ but not to normal, and

TABLE III

Effects of therapy on body fluid and electrolyte composition in 9 subjects with primary hyperaldosteronism

\begin{tabular}{|c|c|c|c|c|c|c|c|c|c|}
\hline Subject & Procedure & Body wt & BP & $\begin{array}{c}\text { Serum } \\
\text { osm. }\end{array}$ & $\begin{array}{l}\mathrm{ECF} \\
\left(\mathrm{S}^{36 \mathrm{O}_{4}}\right. \\
\text { space) }\end{array}$ & $\mathrm{Nas}$ & $\mathrm{K}_{\mathrm{s}}$ & $\begin{array}{c}\mathrm{Na} a / \\
\text { body wt }\end{array}$ & $\begin{array}{c}\mathrm{K}_{\mathrm{o}} / \\
\text { body wt }\end{array}$ \\
\hline L.B. & $\begin{array}{l}\text { Preop. } \\
\text { Postop. } 6 \text { mos. }\end{array}$ & $\begin{array}{c}\mathrm{kg} \\
56.8 \\
55.2\end{array}$ & $\begin{array}{l}m m \mathrm{Hg} \\
200 / 130 \\
140 / 90\end{array}$ & $\begin{array}{l}m O s m / L \\
296 \\
303\end{array}$ & $\begin{array}{c}L \\
8.97 \\
8.99\end{array}$ & $\begin{array}{c}m E q / L \\
145 \\
139\end{array}$ & $\begin{array}{c}m E q / L \\
2.9 \\
4.1\end{array}$ & $\begin{array}{l}m E q / k g \\
2,286 \\
2,239\end{array}$ & $\begin{array}{r}m E q / k g \\
1,335 \\
1,872\end{array}$ \\
\hline J.B. & $\begin{array}{l}\text { Preop. } \\
\text { Preop. K loading* } \\
\text { Postop. } 6 \text { wks. }\end{array}$ & $\begin{array}{l}57.8 \\
55.4 \\
54.8\end{array}$ & $\begin{array}{l}210 / 125 \\
210 / 135 \\
164 / 110\end{array}$ & $\begin{array}{l}277 \\
272 \\
256\end{array}$ & $\begin{array}{l}9.35 \\
9.11 \\
9.20\end{array}$ & $\begin{array}{l}137 \\
133 \\
124\end{array}$ & $\begin{array}{l}2.5 \\
4.2 \\
3.8\end{array}$ & $\begin{array}{l}2,239 \\
1,940 \\
1,759\end{array}$ & $\begin{array}{l}1,398 \\
1,828 \\
2,227\end{array}$ \\
\hline M.C. & $\begin{array}{l}\text { Preop. } \\
\text { Postop. } 3 \text { wks. } \\
\text { Postop. } 6 \text { mos. }\end{array}$ & $\begin{array}{l}60.0 \\
58.2 \\
60.5\end{array}$ & $\begin{array}{l}180 / 110 \\
130 / 85 \\
125 / 80\end{array}$ & $\begin{array}{l}291 \\
290 \\
292\end{array}$ & & $\begin{array}{l}141 \\
139 \\
135\end{array}$ & $\begin{array}{l}2.5 \\
4.9 \\
4.6\end{array}$ & $\begin{array}{l}2,912 \\
2,330 \\
2,352\end{array}$ & $\begin{array}{l}1,175 \\
1,863 \\
2,113\end{array}$ \\
\hline D.G. & $\begin{array}{l}\text { Preop. } \\
\text { Postop. } 7 \text { mos. }\end{array}$ & $\begin{array}{l}53.4 \\
55.0\end{array}$ & $\begin{array}{l}190 / 120 \\
130 / 85\end{array}$ & $\begin{array}{l}295 \\
293\end{array}$ & $\begin{array}{l}8.81 \\
8.69\end{array}$ & $\begin{array}{l}140 \\
140\end{array}$ & $\begin{array}{l}2.6 \\
4.2\end{array}$ & $\begin{array}{l}2,353 \\
1,790\end{array}$ & $\begin{array}{l}1,521 \\
2,526\end{array}$ \\
\hline J.M. & $\begin{array}{l}\text { Pre.op. } \\
\text { Preop. K loading } \dagger \\
\text { Postop. } 7 \text { mos. }\end{array}$ & $\begin{array}{l}83.6 \\
84.5 \\
85.7\end{array}$ & $\begin{array}{l}215 / 130 \\
225 / 130 \\
180 / 105\end{array}$ & $\begin{array}{l}289 \\
289 \\
292\end{array}$ & $\begin{array}{l}10.8 \\
11.2 \\
10.7\end{array}$ & $\begin{array}{l}139 \\
139 \\
140\end{array}$ & $\begin{array}{l}3.3 \\
4.3 \\
4.0\end{array}$ & $\begin{array}{l}2,823 \\
2,874 \\
3,099\end{array}$ & $\begin{array}{l}2,298 \\
2,730 \\
3,670\end{array}$ \\
\hline M.A. & $\begin{array}{l}\text { Preop. } \\
\text { Postop. } 2 \text { mos. } \\
\text { Postop. } 7 \text { mos. }\end{array}$ & $\begin{array}{l}82.1 \\
77.2 \\
84.6\end{array}$ & $\begin{array}{l}165 / 110 \\
155 / 105 \\
160 / 110\end{array}$ & $\begin{array}{l}287 \\
289\end{array}$ & $\begin{array}{l}13.1 \\
11.1\end{array}$ & $\begin{array}{l}138 \\
140 \\
142\end{array}$ & $\begin{array}{l}3.5 \\
4.1 \\
4.1\end{array}$ & $\begin{array}{l}3,649 \\
3,347 \\
3,572\end{array}$ & $\begin{array}{l}2,591 \\
3,134 \\
3,049\end{array}$ \\
\hline C.B. & $\begin{array}{l}\text { Preop. } \\
\text { Postop. } 13 \text { mos. }\end{array}$ & $\begin{array}{l}68.2 \\
65.4\end{array}$ & $\begin{array}{l}220 / 135 \\
170 / 110\end{array}$ & $\begin{array}{l}290 \\
287\end{array}$ & $\begin{array}{l}13.8 \\
9.28\end{array}$ & $\begin{array}{l}142 \\
139\end{array}$ & $\begin{array}{l}3.5 \\
4.3\end{array}$ & $\begin{array}{l}2,623 \\
1,648\end{array}$ & $\begin{array}{l}1,997 \\
2,236\end{array}$ \\
\hline A.H. & $\begin{array}{l}\text { Preop. } \\
\text { Postop. } 16 \text { mos. }\end{array}$ & $\begin{array}{l}51.8 \\
50.2\end{array}$ & $\begin{array}{l}210 / 125 \\
180 / 110\end{array}$ & $\begin{array}{l}294 \\
289\end{array}$ & $\begin{array}{l}8.78 \\
7.83\end{array}$ & $\begin{array}{l}148 \\
141\end{array}$ & $\begin{array}{l}2.8 \\
4.3\end{array}$ & $\begin{array}{l}2,212 \\
2,405\end{array}$ & $\begin{array}{l}1,414 \\
1,612\end{array}$ \\
\hline B.G. & $\begin{array}{l}\text { Preop. } \\
\text { Postop. } 16 \text { mos. }\end{array}$ & $\begin{array}{l}61.8 \\
66.6\end{array}$ & $\begin{array}{l}210 / 120 \\
135 / 90\end{array}$ & $\begin{array}{l}292 \\
293\end{array}$ & $\begin{array}{l}13.0 \\
10.4\end{array}$ & $\begin{array}{l}145 \\
140\end{array}$ & $\begin{array}{l}2.6 \\
4.1\end{array}$ & $\begin{array}{l}2,621 \\
3,043\end{array}$ & $\begin{array}{l}1,396 \\
1,788\end{array}$ \\
\hline
\end{tabular}

* Cumulative potassium intake for 8 days $=1,772 \mathrm{mEq}$.

$\dagger$ Cumulative potassium intake for 4 days $=957 \mathrm{mEq}$. 
BODY FLUID AND ELECTROLYTES IN MINERALOCORTICOID HYPERTENSION

TABLE IV

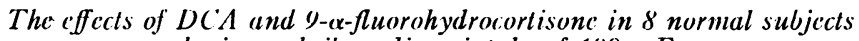
during a daily sodium intake of $180 \mathrm{mEq}$

\begin{tabular}{|c|c|c|c|c|c|c|c|c|c|c|c|}
\hline Subject & Sex & Age & Procedure & Body wt & BP & $\begin{array}{c}\text { Serum } \\
\text { osm. }\end{array}$ & $\begin{array}{l}\mathrm{ECF} \\
\left(\mathrm{S}^{35} \mathrm{O}_{4}\right. \\
\text { space })\end{array}$ & $\mathrm{Nas}$ & $K_{s}$ & $\mathrm{Na}_{\theta}$ & $\mathrm{K}_{\mathbf{e}}$ \\
\hline J.W. & $\mathbf{M}$ & $\begin{array}{c}49 \\
.\end{array}$ & $\begin{array}{l}\text { Control } \\
\text { Fluoro.* }\end{array}$ & $\begin{array}{c}k g \\
66.4 \\
68.2\end{array}$ & $\begin{array}{c}m m H g \\
108 / 64 \\
116 / 70\end{array}$ & $\begin{array}{c}m O s m / L \\
293 \\
294\end{array}$ & $\begin{array}{c}L \\
9.2 \\
11.1\end{array}$ & $\begin{array}{c}m E q / L \\
144 \\
148\end{array}$ & $\begin{array}{c}m E q / L \\
3.54 \\
3.29\end{array}$ & $\begin{array}{c}m E q \\
2,700 \\
3,363\end{array}$ & $\begin{array}{c}m E q \\
3,619 \\
3,674\end{array}$ \\
\hline F.W. & $\mathrm{F}$ & 25 & $\begin{array}{l}\text { Control } \\
\text { Fluoro.* }\end{array}$ & $\begin{array}{l}62.5 \\
62.9\end{array}$ & $\begin{array}{l}124 / 84 \\
124 / 90\end{array}$ & $\begin{array}{l}290 \\
285\end{array}$ & $\begin{array}{l}9.31 \\
9.50\end{array}$ & $\begin{array}{l}140 \\
149\end{array}$ & $\begin{array}{l}4.26 \\
3.98\end{array}$ & $\begin{array}{l}2,442 \\
2,570\end{array}$ & $\begin{array}{l}2,651 \\
2,621\end{array}$ \\
\hline T.M. & $\mathbf{M}$ & 33 & $\begin{array}{l}\text { Control } \\
\text { Fluoro.* }\end{array}$ & $\begin{array}{l}88.2 \\
90.0\end{array}$ & $\begin{array}{l}120 / 75 \\
140 / 90\end{array}$ & $\begin{array}{l}287 \\
291\end{array}$ & $\begin{array}{l}11.9 \\
12.6\end{array}$ & $\begin{array}{l}145 \\
145\end{array}$ & $\begin{array}{l}4.46 \\
4.01\end{array}$ & $\begin{array}{l}3,098 \\
3,519\end{array}$ & $\begin{array}{l}3,787 \\
3,478\end{array}$ \\
\hline H.T. & $\mathbf{M}$ & 36 & $\begin{array}{l}\text { Control } \\
\text { Fluoro.* }\end{array}$ & $\begin{array}{l}74.5 \\
75.8\end{array}$ & $\begin{array}{l}118 / 76 \\
116 / 72\end{array}$ & $\begin{array}{l}290 \\
289\end{array}$ & $\begin{array}{l}11.0 \\
10.9\end{array}$ & $\begin{array}{l}144 \\
149\end{array}$ & $\begin{array}{l}4.54 \\
4.20\end{array}$ & $\begin{array}{l}3,185 \\
3,315\end{array}$ & $\begin{array}{l}2,978 \\
2,876\end{array}$ \\
\hline E.G. & $\mathbf{M}$ & 24 & $\begin{array}{l}\text { Control } \\
\text { DCAt }\end{array}$ & $\begin{array}{l}80.7 \\
80.7\end{array}$ & $\begin{array}{l}106 / 62 \\
130 / 80\end{array}$ & $\begin{array}{l}296 \\
293\end{array}$ & $\begin{array}{l}10.9 \\
14.3\end{array}$ & $\begin{array}{l}141 \\
146\end{array}$ & $\begin{array}{l}4.25 \\
3.39\end{array}$ & $\begin{array}{l}2,906 \\
3,309\end{array}$ & $\begin{array}{l}2,969 \\
2,893\end{array}$ \\
\hline L.S. & $\mathbf{M}$ & 23 & $\begin{array}{l}\text { Control } \\
\text { DCAt }\end{array}$ & $\begin{array}{l}79.6 \\
81.1\end{array}$ & $\begin{array}{l}132 / 82 \\
160 / 104\end{array}$ & $\begin{array}{l}294 \\
307\end{array}$ & $\begin{array}{l}10.8 \\
11.2\end{array}$ & $\begin{array}{l}141 \\
151\end{array}$ & $\begin{array}{l}4.10 \\
3.51\end{array}$ & $\begin{array}{l}3,458 \\
3,729\end{array}$ & $\begin{array}{l}3,271 \\
3,274\end{array}$ \\
\hline A.L. & $\mathbf{M}$ & 34 & $\begin{array}{l}\text { Control } \\
\text { Fluoro.* }\end{array}$ & $\begin{array}{l}54.5 \\
53.6\end{array}$ & $\begin{array}{l}138 / 88 \\
160 / 108\end{array}$ & $\begin{array}{l}290 \\
290\end{array}$ & $\begin{array}{r}9.0 \\
11.2\end{array}$ & $\begin{array}{l}144 \\
144\end{array}$ & $\begin{array}{l}4.50 \\
4.08\end{array}$ & $\begin{array}{l}2,478 \\
2,705\end{array}$ & $\begin{array}{l}2,111 \\
1,916\end{array}$ \\
\hline $\mathrm{EP}$ & $\mathrm{F}$ & 53 & $\begin{array}{l}\text { Control } \\
\text { Fluoro.* }\end{array}$ & $\begin{array}{l}58.6 \\
58.6\end{array}$ & $\begin{array}{l}132 / 78 \\
156 / 96\end{array}$ & $\begin{array}{l}288 \\
290\end{array}$ & $\begin{array}{l}9.40 \\
11.4\end{array}$ & $\begin{array}{l}141 \\
143\end{array}$ & $\begin{array}{l}5.24 \\
3.90\end{array}$ & $\begin{array}{l}1,903 \\
2,140\end{array}$ & $\begin{array}{l}1,755 \\
1,512\end{array}$ \\
\hline
\end{tabular}

* 9- $\alpha$-Fluorohydrocortisone, $1.0 \mathrm{mg} /$ day orally for 15 days.

$\dagger$ Desoxycorticosterone acetate, $20 \mathrm{mg} / \mathrm{day}$ i.m. for 21 days.

one has had no reduction in blood pressure. The reduction in blood pressure was usually observed during the first postoperative month and occurred in patients with either adrenal cortical hyperplasia or adrenal cortical adenoma. In all instances, reductions in blood pressure were associated with increases in exchangeable potassuim. The changes in exchangeable sodium were variable however. In Subjects J.M., L.B., A.H. and B.G., postoperative reductions in blood pressure were not associated with reductions in exchangeable sodium, although some reduction in exchangeable sodium was observed in the other five individuals.

Neither of the two patients repleted with potassium preoperatively had a reduction in blood pressure.

\section{Mineralocorticoid drug therapy}

The complete results are tabulated in Table V. Five of the eight normal subjects treated with either DCA or fluorohydrocortisone had increases

TABLE V

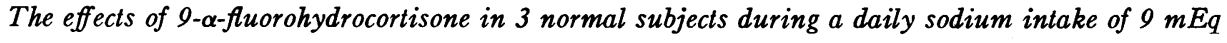

\begin{tabular}{|c|c|c|c|c|c|c|c|c|}
\hline Subject & Sex & Age & $\mathrm{Na}$ intake & Procedure & Duration & Weight & BP & $\underset{\text { balance }}{\text { Net } \Delta \mathrm{Na}}$ \\
\hline T.M. & M & $\begin{array}{l}y r s \\
33\end{array}$ & $\begin{array}{c}m E q / \text { day } \\
180 \\
9\end{array}$ & $\begin{array}{l}\text { Control } \\
\text { Fluoro.* }\end{array}$ & $\begin{array}{c}\text { days } \\
7 \\
14\end{array}$ & $\begin{array}{c}k g \\
88.2 \\
88.1\end{array}$ & $\begin{array}{l}m m \mathrm{Hg} \\
120 / 70 \\
122 / 72\end{array}$ & $\begin{array}{l}m E q \\
-20 \\
+8\end{array}$ \\
\hline A.L. & $\mathbf{M}$ & 34 & $\begin{array}{r}180 \\
9\end{array}$ & $\begin{array}{l}\text { Control } \\
\text { Fluoro.* }\end{array}$ & $\begin{array}{r}7 \\
14\end{array}$ & $\begin{array}{l}54.5 \\
54.7\end{array}$ & $\begin{array}{l}138 / 88 \\
136 / 84\end{array}$ & $\begin{array}{l}-39 \\
+60\end{array}$ \\
\hline E.P. & $\mathrm{F}$ & 43 & $\begin{array}{r}180 \\
9\end{array}$ & $\begin{array}{l}\text { Control } \\
\text { Fluoro.* }\end{array}$ & $\begin{array}{r}7 \\
14\end{array}$ & $\begin{array}{l}58.6 \\
58.6\end{array}$ & $\begin{array}{l}132 / 78 \\
130 / 82\end{array}$ & $\begin{array}{l}+18 \\
-3\end{array}$ \\
\hline
\end{tabular}

* 9- $\alpha$-Fluorohydrocortisone, $1.0 \mathrm{mg} /$ day orally. 
TABLE VI

Comparison of changes in body $\mathrm{Na}$ and $K$ by melabolic balance and radioisotope space measurements

\begin{tabular}{|c|c|c|c|c|c|}
\hline Subject & $\begin{array}{c}\text { Period } \\
\text { of obser- } \\
\text { vation }\end{array}$ & $\begin{array}{c}\text { Metabolic } \\
\text { balance } \\
\Delta \mathrm{Na}\end{array}$ & $\mathrm{Na} e$ & $\begin{array}{c}\text { Metabolic } \\
\text { balance } \\
\Delta \mathrm{K}\end{array}$ & $\mathrm{K}_{\boldsymbol{\theta}}$ \\
\hline & days & $m E q$ & & $m E q$ & \\
\hline $\begin{array}{l}\text { J.M. } \\
\text { E.B. }\end{array}$ & $\begin{array}{l}17 \\
23\end{array}$ & $\begin{array}{l}-160 \\
-86\end{array}$ & $\begin{array}{l}+59 \\
+102\end{array}$ & $\pm_{-2}^{+151}$ & $\begin{array}{r}+138 \\
+144\end{array}$ \\
\hline & & -173 & -350 & +249 & +358 \\
\hline A.L. & 14 & $\begin{array}{r}+274 \\
\end{array}$ & +227 & & \\
\hline $\begin{array}{l}\text { L.S. } \\
\text { E.G. }\end{array}$ & $\begin{array}{l}14 \\
14\end{array}$ & $\begin{array}{l}+376 \\
+383\end{array}$ & $\begin{array}{r}+271 \\
+403\end{array}$ & & \\
\hline
\end{tabular}

in blood pressure of greater than $20 / 10 \mathrm{~mm} \mathrm{Hg}$ while on a dietary sodium intake of $180 \mathrm{mEq}$ per day, although no increase in blood pressure was observed in all three of these five subjects who were treated with fluorohydrocortisone when dietary sodium was restricted to less than $9 \mathrm{mEq}$ per day. In each instance when blood pressure increased following mineralocorticoid administration, there was a definite increase in exchangeable sodium, ranging from 227 to $421 \mathrm{mEq}$, along with slight increases in the radiosulfate space and reductions in serum potassium. Body weight, serum osmolality and exchangeable potassium in these five subjects did not show consistent alterations.

\section{Simultaneous metabolic balance, exchangeable} sodium and exchangeable potassium measurements

The complete results are tabulated in Table VI. Changes in body sodium and potassium as measured by radioisotope dilution techniques were comparable with those observed using the metabolic balance method. The maximum difference between the values obtained by each method was $219 \mathrm{mEq}$ for sodium and $146 \mathrm{mEq}$ for potassium -less than 10 and 8 per cent, respectively, of the total exchangeable sodium and potassium values.

\section{DISCUSSION}

The body fluid and electrolyte composition of patients with primary hyperaldosteronism differs from that observed in patients with other types of hypertension studied in this laboratory. Although, as in nonedematous patients with malignant hypertension or hypertension complicated by heart failure, there is a significant increase in ex- changeable sodium and extraccllular fluid volume, the severe degree of body potassium depletion present in this group has not been observed in any other untreated hypertensive state.

The relationship of the changes in body fluids and electrolytes to the pathogenesis of "mineralocorticoid" hypertension remains obscure. It is unlikely that absolute changes in extracellular fluid volume or the body content of sodium and potassium can be used to explain the development of the hypertension. With respect to extracellular fluid volume and exchangeable sodium, although statistically significant elevations of these measurements were present in the aldosterone group, many of the values recorded appeared to be within the normal range, and postoperative reductions in blood pressure following adrenal surgery in five of eight patients were not associated with reductions in extracellular fluid volume or exchangeable sodium. With respect to body potassium, the exchangeable potassium was reduced in every case preoperatively and increased to normal levels in all subjects studied following adrenal surgery. However, preoperative dietary repletion of exchangeable potassium toward normal was not associated with a reduction in blood pressure, nor was repletion of body potassium following surgery always associated with a reduction in blood pressure. In some instances administration of "steroidal antagonist" compounds for brief periods to these patients (or to individuals pretreated with mineralocorticoid drugs) caused potassium retention without necessarily affecting the blood pressure (3). An indirect effect of potassium depletion on the development of the hypertension through such factors as the production of potassium depletion nephropathy cannot, however, be excluded. Likewise, although the hypertension may not have been related to absolute changes in exchangeable sodium and potassium, local electrolyte redistribution cannot be ruled out by the techniques employed. Such shifts may play an important role in the development of the hypertension.

Similar to the observations in experimentallyinduced mineralocorticoid hypertension of animals $(4,5)$, blood pressure elevation in the normotensive subjects treated with mineralocorticoid drugs is prevented when the dietary intake of sodium is restricted. However, mild elevation in blood 
pressure is observed in some of the subjects when a liberal dietary intake of sodium is administered (6). As in the patients with primary hyperaldosteronism, it would appear that the changes in blood pressure with mineralocorticoid drugs may not be explained by mere absolute changes in exchangeable sodium, potassium or extracellular fluid volume. Not all subjects exhibiting increases in exchangeable sodium and extracellular fluid volume with mineralocorticoid drugs had increases in blood pressure, and the changes in exchangeable potassium with treatment were generally small and variable. Treatment with steroidal antagonist compounds likewise did not necessarily reduce the blood pressure to control levels (3) even though body sodium balance did return to or toward control levels. The differences in the severity of the hypertension and the degree of potassium depletion in the drug-treated group as compared with the patients with primary aldosteronism might be a result of the differences in duration of mineralocorticoid excess, the unphysiological doses of mineralocorticoid drugs that were used in this study, or possible differences in vascular reactivity between the two groups.

The close correlation between the radioisotope dilution and metabolic balance measurements is in agreement with previous reports (7-9), and again points to the usefulness of these techniques in evaluating changes in body electrolytes, particularly over long periods of time when metabolic balance measurements become impractical and difficult. From this study as well as others previously reported $(9,10)$, it would appear that measurements of exchangeable potassium are useful in determining the degree of potassium depletion present and yield information not obtainable from serum potassium determinations. Severe degrees of potassium depletion were present in all subjects with aldosteronism even though serum potassium levels were at times only slightly reduced. In the subjects treated with mineralocorticoid drugs, marked changes in serum potassium occurred at times without appreciable change in exchangeable potassium.

\section{SUM MARY}

1. Values of exchangeable sodium, potassium and extracellular fluid volume have been com- pared in 11 patients with primary aldosteronism and matched normal controls.

2. The results indicate that primary aldosteronism, unlike other uncomplicated hypertensive states, is characterized by a combination of slight increases in exchangeable sodium and extracellular fluid volume and marked reductions in exchangeable potassium.

3. Corrective adrenal surgery has resulted in restoration of exchangeable potassium to predicted normal levels and in some instances in reduction of exchangeable sodium and extracellular fluid volume.

4. Blood pressure elevation in normal subjects treated with mineralocorticoid drugs is associated with significant increases in exchangeable sodium and extracellular fluid volume.

5. The hypertension associated with mineralocorticoid excess does not appear to be directly related to absolute changes in body electrolytes.

\section{ACKNOWLEDGMENT}

We are indebted to Drs. Arnold S. Relman and William B. Schwartz for the use of the metabolic balance data on the patients with primary aldosteronism.

\section{REFERENCES}

1. Hollander, W., Chobanian, A. V., and Burrows, B. A. Body fluid and electrolyte composition in arterial hypertension. I. Studies in essential, renal and malignant hypertension. J. clin. Invest. 1961, 40, 408.

2. Relman, A. S., and Schwartz, W. Metabolic studies in primary hyperaldosteronism. To be published.

3. Chobanian, A. V., Burrows, B. A., and Hollander, W. The relationship of blood pressure to changes in body fluids and electrolytes in steroid hypertension. Clin. Res. 1958, 6, 227.

4. Selye, H., Hall, C. E., and Rowley, E. M. Malignant hypertension produced by treatment with desoxycorticosterone acetate and sodium chloride. Canad. med. Ass. J. 1943, 49, 88.

5. Gross, F., Loustalot, P., and Sulser, F. Die Bedeutung von Kochsalz für den Cortexon-Hochdruck der Ratte und den Gehalt der Nieren an pressorischen Substanzen. Naunyn-Schmiedeberg's Arch. exp. Path. Pharmak. 1956, 229, 381.

6. Perera, G. A., Knowlton, A. I., Lowell, A., and Loeb, R. F. Effect of desoxycorticosterone acetate on the blood pressure of man. J. Amer. med. Ass. 1944, 125, 1030.

7. Wilson, G. M., Olney, J. M., Brooks, L., Myrden, J. A., Ball, M. R., and Moore, F. D. Body sodium and potassium. II. A comparison of meta- 
bolic balance and isotope dilution methods of study. Metabolism 1954, 3, 324.

8. Martin, M. M., and Walker, G. Studies with $\mathrm{Na}^{22}$ An assessment of sodium balance and distribution. Metabolism 1957, 6, 466.

9. Burrows, B. A., and Ross, J. F. The use of radiosodium and radiopotassium tracer studies in man in
Proc. Int. Conf. on Peaceful Uses of Atomic Energy. New York, United Nations, 1956, vol. 10, p. 430.

10. Leibman, J., and Edelman, I. S. Interrelations of plasma potassium concentration, plasma sodium concentration, arterial $\mathrm{pH}$ and total exchangeable potassium. J. clin. Invest. 1959, 38, 2176. 